\title{
Kazimierz Popielski, Piotr Mamcarz, Trauma egzystencjalna a wartości, Difin, Warszawa 2015, ss. 153
}

Trauma egzystencjalna to „negatywne doświadczenie egzystencjalnie znaczące (życiowo ważne) lokujące się w pamięci autobiograficznej i przejawiające się licznymi symptomami noo-psychosomatycznymi”"

Autorzy omawianej książki prezentują przede wszystkim teoretyczną warstwę traumy oraz dokonują szczegółowego podziału jej rodzajów (wyróżniają traumę fizyczną, psychiatryczną i postkulturową). Już samo pojęcie t r a u m y wywołuje negatywne skojarzenia lub niechęć. Trauma łączy się zwykle z bólem, cierpieniem, przemocą, z negacją wszelkich pozytywnych wartości w życiu. Popielski twierdzi, że trauma staje się problemem wielowymiarowym w tym sensie, że wywiera wpływ na wszystkie aspekty ludzkiej aktywności: biologiczny, psychologiczny, noetyczny (duchowy) i społeczny².

Zrozumienie traumy jest poza zasięgiem rozumu i naszej - ludzkiej wyobraźni, bo traumatyczne wydarzenia wykraczają poza zwykły porządek społeczny; porządek rzeczy, który daje ludziom poczucie sensu, bezpieczeństwa, związku z innymi, kontroli, przekraczają one zwykle też nasze zdolności przystosowawcze. Zmuszają też często człowieka do konfrontacji z poczuciem skrajnej rozpaczy, bezradności i przerażenia, wywołując jednocześnie jego dramatyczne

${ }^{1}$ Kazimierz Popielski, Piotr Mamcarz, Trauma egzystencjalna a wartości (Warszawa: Difin, 2015), 144.

${ }^{2}$ Ibidem, 19. 
reakcje. Jeśli sprawcą ich jest człowiek, należy je nazwać zbrodnią, bo trauma to gwałt zadany nie tylko systemowi nerwowemu, co samemu ,ja”3.

Trauma niszczy sferę poznawczo-behawioralną człowieka, powodując obniżenie sprawczości, funkcji motywacyjnej i ogólną demobilizację sfery poznawczo-emocjonalnej. Z traumą związanany jest zespół stresu pourazowego.

W praktyce lekarskiej i w literaturze przedmiotu wyróżnia się kilka sposobów rozumienia zespołu pourazowego. Zgodnie z jednym z nich, jest to zwykła, codzienna reakcja na stres, powstająca w momencie, gdy człowiek uczestniczy w jednorazowym wydarzeniu traumatycznym. Skutki natury psychicznej takiego wydarzenia są po prostu nietrwałe. Według innej klasyfikacji zespół pourazowy jest katastroficzną reakcją na stres, która skutkuje dezintegracją funkcji poznawczych, bezsennością, paniką, dezorientacją czy chronicznym niepokojem ${ }^{4}$. Najogólniej rozumiany stres pourazowy łączy się z takimi dolegliwościami, jak stany depresyjne, napady złości, agresji i brak zdolności do koncentracji. Człowiek będący w takim stanie zwykle nadużywa środków psychoaktywnych i alkoholu, wywołujących kolejne zaburzenia osobowościowe i stany lękowe. W niektórych przypadkach dochodzi do powstania tak zwanej os ob ow ości postrau matycznej, która jest skutkiem długotrwałego narażenia na oddziaływanie czynników ogólnie szkodliwych. Osobowość tego rodzaju charakteryzuje się impulsywnością, labilnością, autodestrukcyjnością i agresywnością. Trzeba jednak uwzględnić jeszcze jeden przypadek stanu pourazowego, który dotyczy osób zaledwie pośrednio uczestniczących $\mathrm{w}$ procesie traumatycznym. Przede wszystkim dotyczy to osób wykonujących zawody zwiększonego ryzyka: lekarzy, strażaków, policjantów i ratowników medycznych ${ }^{5}$.

W drugim rozdziale autorzy publikacji koncentrują się na aspekcie aksjologicznym ludzkiej egzystencji. Popielski wychodzi z założenia, że właściwie rozpoznane wartości są fundamentem rozwoju jednostki, jej sprawnego funkcjonowania w świecie społeczno-kulturowym. „Wartości pomagają wyjaśnić ludzkie motywy, zachowania oraz przebieg procesów społecznych. Są one rozpatrywane zarówno jako przedmioty ludzkich pragnień, jak i normy

\footnotetext{
${ }^{3}$ Radny Alina. 2011. „Wpływ traumy na psychikę. Psychoterapia ofiary”. Neurokognitywistyka w patologii i zdrowiu 2009-2011, Sympozja I, Roczniki Pomorskiej Akademii Medycznej w Szczecinie 1: 106.

${ }^{4}$ Popielski, Mamcarz, Trauma egzystencjalna a wartości, 20.

${ }^{5}$ Ibidem, 21.
} 
funkcjonujące w grupach społecznych. Wartości służą samej jednostce, życiu zbiorowemu i psychoekologicznemu funkcjonowaniu egzystencji”'. Autorzy książki podkreślają, że wartości stanowią wręcz podstawę prawidłowego i pełnego życia, a jeśli ludzie dokonują świadomego wyboru celów, ich siła motywacyjna wzrasta i możliwe staje się konstruktywne budowanie spójnej tożsamości osoby.

Wartości służą twórczemu byciu, rozwijaniu i stawaniu się jednostki. System wartości pełni też funkcję rozwoju osobowości, jej dynamiki i struktury, funkcję wewnętrznego mechanizmu motywacyjnego, który aktywizuje jednostkę do działania poprzez system przyjętych reguł postępowania, a także wpływa na dokonywanie wyborów i decyzji. $\mathrm{W}$ ostatecznym wymiarze wartości wyznaczają sposoby indywidualnego postrzegania świata oraz emocjonalny stosunek do obiektów, zjawisk i zdarzeń podlegających wartościowaniu .

Głównym zadaniem autorów książki jest jednak zdefiniowanie traumy egzystencjalnej. Trauma, jak wiadomo, może pociągać za sobą także konstruktywne i pozytywne skutki dla ludzkiego życia. Popielski twierdzi, że przeżycie traumatyczne może być również d ośw i a d cze n i em eg zyst e ncjaln ie $\mathrm{z} n$ a c z ą c y m, niosącym ze sobą wyższe wartości i treści społecznie twórcze i osobowościowo wzbogacające ${ }^{8}$. Badacze zwracają uwagę na fakt, że człowiek stale poszukuje sensu, znaczenia, wartości. To wszystko zaś buduje jego egzystencję i decyduje o jakości jego zmagań ze światem. Wszystko, co otacza człowieka jest przepełnione treścią (nawet sytuacje traumatyczne i graniczne), choć czasem nie jesteśmy w stanie do końca tego życia zrozumieć, a tym bardziej ująć w pojęciowe reguły.

Doświadczenia i wspomnienia traumatyzujące zalegają w ludzkiej przeszłości, teraźniejszość „tu i teraz” dodaje kolejnych niekorzystnych doznań, zaś przyszłość ciąży ogromem niepewności i lęków o to, co jeszcze może się nam przydarzyć. Popielski często w swych publikacjach podkreśla, że człowiek konfrontuje się ze swoją osobistą historią i biografią. By przezwyciężyć cierpienie i ból człowiek jako podmiot moralny powinien zaakceptować i „rozliczyć się” z okrucieństwem przeszłości ${ }^{9}$. Teraźniejszość nieprzerwanie aktualizuje się i staje, jest punktem, w którym zbiegają się nasze przeży-

\footnotetext{
${ }^{6}$ Ibidem, 52.

${ }^{7}$ Ibidem.

${ }^{8}$ Ibidem, 55.

${ }^{9}$ Ibidem, 62.
} 
cia i nadzieje na lepszą przyszłość. W teraźniejszości dokonujemy „rzeczy niemożliwych", by w akcie transgresji (transcendowania) osiągnąć poczucie bezpieczeństwa i stabilizacji.

Omawiana publikacja zawiera także próby empirycznego potwierdzenia (zweryfikowania) teoretycznych ustaleń dotyczących traumy egzystencjalnej. Popielski i Mamcarz dokonują szczegółowego opisu funkcjonowania człowieka dotkniętego piętnem traumy, analizują relację między systemem aksjologicznym a pojawieniem się traumy egzystencjalnej, omówiają również związek między „strukturą osobowości i funkcjonowaniem noo-psychosomatycznym a traumą egzystencjalną"10. Autorzy dookreślając pojęcie traumy zastosowali przede wszystkim dwie metody: test noo-dynamiki i kwestionariusz traumy egzystencjalnej. W celu weryfikacji przyjętych hipotez autorzy przeprowadzili badania na trzystuosobowej grupie. Na tej podstawie uznali, że występuje korelacja między noo-dynamiką, niepewnością, labilnością emocjonalną a traumą egzystencjalną. Nie została jednak potwierdzona hipoteza o ścisłej relacji pomiędzy wartością a traumą egzystencjalną. Osoby niestabilne psychicznie, mające poczucie bezsensu życia, przejawiające silny niepokój mają większą tendencję do przeżycia traumy i odczucia jej negatywnych skutków dla higieny fizycznej, psychicznej i duchowej.

Aleksandra Kondrat Uniwersytet Mikołaja Kopernika, Toruń e-mail: moskwa.ros@gmail.com

${ }^{10}$ Ibidem, 144. 